\title{
Analysis of waste management system reform in Russia
}

\author{
Nadezhda Abramova ${ }^{1, *}$ \\ ${ }^{1}$ Moscow State University of Civil Engineering, 26, Yaroslavskoye sh., 129337, Moscow, Russia
}

\begin{abstract}
The article deals with the current problems of reforming the MSW management system in Russia, starting in 2019. The Russian Ministry of Natural Resources is responsible for the legal regulation of waste reform. Russian Environmental Operator (REO) was created for organizational management. Methods of analysis of documents and secondary data were used to get acquainted with the experience of reforming the waste management system. The analysis was carried out at both the federal and regional levels. An institutional and functional analysis of the subjects of waste management in Russia is presented. The planned indicators of the garbage reform are defined - utilization up to $36 \%$ and processing up to 60 . The analysis at the regional level is carried out on the example of several subjects of the Russian Federation: Moscow, the Moscow Region, the Republic of Tatarstan, the Primorsky Territory, the Kaliningrad Region. Having carefully analyzed the documents, the authors identified the main problems of the reform, such as the imperfection of the legislative framework and the lack of funding for the creation of an appropriate infrastructure.
\end{abstract}

\section{Introduction}

In 2019, a reform on the management of solid municipal waste was launched. In order to optimize the management system, it is advised to refer to the waste management hierarchy. The hierarchy establishes a priority order within the framework of a set of measures in the field of waste: after the prevention of waste generation, it is reused, recycled, reclaimed, and only then, as the least preferred option, disposed, in particular, buried. The start of reform highlights the need to improve overall solid waste management and recycling programs, including efforts to reduce waste generation and increase the amount of resources used in waste management systems.

The main legislative act for the reform is FZ-89 of June 24, 1998. Amendments are adopted to it within the framework of changing the waste management system. On January 1, 2019, the federal law of December 31, 2017 "On Amendments to the Federal Law "On Production and Consumption Waste" came into force, and this law became the basis for the implementation of the so-called waste reform.

The Russian Ministry of Natural Resources is responsible for the legal regulation of waste reform. In addition, Russian Environmental Operator (REO) was established. It was

\footnotetext{
* Corresponding author: AbramovaNV@mgsu.ru
} 
supposed to collect statistical information on MSW generation and regulate the financing of the reform. It is also supposed to develop a federal scheme for the management of MSW based on the analysis of regional schemes, determine the needs for processing plants. This scheme is under development. Regional operators were created in the constituent entities of the Russian Federation. New tariffs were set for waste disposal. The regional operator is engaged in both collection and processing of waste. It also cleans up any illegal dumps found on its territory. Payment for MSW handling has ceased to be listed in general house services and transferred to utilities. In addition, a requirement was introduced for garbage trucks to be equipped with a GLONASS system in order to track the transportation of waste.

In January 2020, the development of action plans for separate waste collection began. And only four regions have already introduced such a system: Moscow, Moscow Region, Nizhny Novgorod, and Mordovia. During the reform process, regional operators had to install containers for recyclable materials, but this was not funded from the federal budget. And only on September 23, 2020, a decree on the rules for granting subsidies to regions for the purchase of containers was signed. To participate in the selection, regional operators apply for a subsidy in a certain form. But the Ministry of Natural Resources has not yet approved this form, and the regions do not have the opportunity to receive subsidies.

The constituent entities of the Russian Federation make a territorial waste management scheme. Such a scheme contains: sources of waste generation, amount of waste generation, targets, places of accumulation, location of objects, flow diagram, planned objects. As of February 1, 2020, 79\% of the regions started working according to the new scheme. But an exception was made for 4 constituent entities of the Russian Federation: Khabarovsk Territory, the Jewish Autonomous Region, Moscow and St. Petersburg (the transition was postponed until January 1, 2022). Another 2 constituent entities of the Russian Federation Kamchatka and Krasnodar Territories - partially switched to the new scheme.

\section{Research methodology and sources of information}

Significant changes in waste management in Europe have occurred due to the concepts of "Sustainable development", "Circular Economy". Many assumptions about the benefits of improving the management of natural resources are considered, and the twelfth UN Sustainable Development Goal (SDG) mentions the development of sustainable consumption and production [1,2]. In this direction is the concept of a circular economy $(\mathrm{CE})$, in which linear economies are replaced by closed loops, such as in Europe $[3,4]$ and China [5,6]. From the CE point of view, waste should be considered not as an expense, but as a resource $[7,8]$. Waste management and resource recovery activities are therefore becoming important drivers.

An analysis of the morphology of solid waste in Sweden showed that about $31-36 \%$ is plastic packaging and paper that has not been sorted $[9,10]$. Thus, there is great potential for reducing tailings and sorting packaging and food waste. A similar pattern is observed in other countries; for example, the European Environment Agency concludes that most countries should make a huge effort to achieve the waste recycling goals set by Europe [11, 12,13]. The World Bank report "What a Waste 2.0"recommends analyzing the following indicators: waste generation, waste morphology, waste collection, disposal methods, and costs [14].

The purpose of this paper was to clarify the current problems in the process of reforming municipal waste management. To achieve this goal, the official sources of the federal and regional levels were analyzed. If we talk about the federal level, then the analysis of the report of the Accounts Chamber has been carried out. At the regional level, an analysis of a number of regulatory documents and publications in the media were made. 
For each constituent entity of the Russian Federation, an analysis of the territorial scheme was carried out, as well as of the passport of the Federal project "Integrated system of MSW management", the passport of the regional project "Integrated system of MSW management", the regional program - a subprogram of the state program in the field of waste management. For the analysis of publications in the media, we used a two-stage qualitative content analysis according to the method of P. Meiring - focus on the main tasks of the study and description of patterns or the "whole" core in the analyzed text. Based on sociological data, you can see the difference between the level of satisfaction with garbage collection in Moscow and St. Petersburg compared to other Russian cities (Table 1). The study included the following subjects of the Russian Federation: Moscow, the Moscow Region, the Republic of Tatarstan, the Primorsky Territory, the Kaliningrad Region.

Table 1. Tell me, please, are you generally satisfied or dissatisfied with the situation with the removal and disposal of household garbage in your locality? (closed question, one answer, $\%$ of all respondents) [15].

\begin{tabular}{|l|c|c|c|}
\hline & All respondents & $\begin{array}{c}\text { Moscow and St. } \\
\text { Petersburg }\end{array}$ & $\begin{array}{c}\text { Cities with millions of } \\
\text { inhabitants }\end{array}$ \\
\hline Rather satisfied & 58 & 71 & 54 \\
\hline Rather dissatisfied & 38 & 28 & 40 \\
\hline $\begin{array}{l}\text { I find it difficult to } \\
\text { answer }\end{array}$ & 4 & 1 & 6 \\
\hline
\end{tabular}

\section{Result}

Here is an institutional and functional analysis of the subjects of waste management in Russia. The state is in charge of legal regulation. Let's list the bodies, federal executive bodies that are involved in legal regulation: the Ministry of Natural Resources, the Ministry of Industry, the Ministry of Construction, Housing and Utilities of the Russian Federation. In 2018, all powers were transferred to the Ministry of Natural Resources. Several bodies carry out legal regulation and supervisory activities - Federal Service for Supervision of Natural Resource Usage, Federal Service for Veterinary and Phytosanitary Surveillance. The activity of social subjects is regulated by formal rules in different fields of interaction: economic, legal, socio-cultural. Levers of influence: legislative regulation of citizens provides municipal services.

\subsection{Analysis at the federal level}

We have analyzed the report of the Accounts Chamber of the Russian Federation "Analysis of the implementation of measures to ensure the environmental safety of the Russian Federation in terms of eliminating accumulated harm objects and forming an integrated system for MSW management" [16]. According to the ministry, $90 \%$ of waste continues to go to landfills. In 2019, the execution of expenditures of the Ministry of Natural Resources of Russia for the activities of the national project amounted to only $39.2 \%$. More than half of the unfulfilled expenditures of the federal budget -10.7 billion rubles out of 18.7 billion rubles - are accounted for the FP"MSW".

The waste reform was launched in part due to the lack of the necessary regulatory framework and the lack of funding under the FP "MSW" program. So, the Ministry of Natural Resources did not adopt regulations at the federal level, and the regions were unable to start the reform. The agency did not allocate funding to PJSC Russian Environmental Operator (REO). The unified state system of MSW accounting was never created. Thus, the planned expenditures of REO for the implementation of measures to 
create an electronic federal scheme for MSW management in the amount of 110.55 million rubles were not funded by the Ministry of Natural Resources of Russia due to the lack of these expenditures in the estimate approved by the company's supervisory board. At the expense of these funds, in December 2019, the Ministry of Natural Resources of Russia provided subsidies to the Ural NII "Ecology" in the amount of 20 million rubles.

To solve the problem of managing the waste management system, you can turn to network modeling, which was an effective method of territorial production management in the USSR. And in the USSR created a powerful system that allows you to motivate, to make and to organize people. It all started back in the late 1920s, during the first five-year plan. At that time, five groups of recyclable resources were identified: glass, waste paper, textiles, tires, and polymers. Moreover, the command planned system of the economy, which did not benefit the Soviet consumer market, worked perfectly here. After all, there was no question of whether secondary materials would be in demand. There was the Gossnab, which was responsible for allocating resources for industry, and it also calculated how much processed raw materials and where to send them. Nowadays, steps are being taken. A federal waste management scheme is being formed, and REO is responsible for this.

In addition, in 2019, the Ministry of Natural Resources of Russia did not provide the constituent entities of the Russian Federation and investors with financial support for the creation of waste management infrastructure facilities. The necessary infrastructure for the disposal and processing of MSW was not funded, which disrupts the possibility of meeting the planned targets -disposal up to $36 \%$ and processing up to $60 \%$ in the total volume of solid municipal waste generated, by 2024: These indicators could be achieved after the construction of sorting plants, the purchase of containers, the purchase of garbage trucks (Table 2).

Table 2. Target indicator "The share of MSW directed to processing and disposal in the total volume of generated MSW" Passport of FP"Integrated MSW Management System".

\begin{tabular}{|l|c|c|c|c|c|c|c|}
\hline & $\mathbf{2 0 1 8}$ & $\mathbf{2 0 1 9}$ & $\mathbf{2 0 2 0}$ & $\mathbf{2 0 2 1}$ & $\mathbf{2 0 2 2}$ & $\mathbf{2 0 2 3}$ & $\mathbf{2 0 2 4}$ \\
\hline For processing & 7 & 12 & 27 & 38 & 40 & 55 & 60 \\
\hline For disposal & 3 & 7 & 16.2 & 22.8 & 24 & 33 & 36 \\
\hline
\end{tabular}

One of the reasons for the problems in the field of waste management is the huge shortage of capacity of enterprises for the disposal, sorting, recycling of waste in most regions of the Russian Federation. In fact, it is necessary to create a new infrastructure, including special containers for waste collection, additional garbage trucks for the removal of recyclable materials, the construction of sorting plants, and incinerators. In the "Integrated system for the treatment of MSW" in part, these tasks are reflected. However, if we look at the sources of funding for the program, we see that only $36 \%$ is funded from the federal budget. And we can conclude that our government shifts the responsibility for the formation of a new infrastructure to the shoulders of the subjects of the Russian Federation and business representatives (Table 3 ).

Table 3. Financial support for the implementation of the federal project "Ecology".

\begin{tabular}{|l|c|}
\hline \multicolumn{1}{|c|}{ Sources of financing } & Total \\
\hline federal budget & 107864.71 \\
\hline $\begin{array}{l}\text { of which interbudgetary transfers to the budgets of the } \\
\text { constituent entity }\end{array}$ & 30973.91 \\
\hline $\begin{array}{l}\text { consolidated budgets of the constituent entities of the } \\
\text { Russian Federation }\end{array}$ & 37318.68 \\
\hline Extra budgetary sources & 182000.0 \\
\hline Total & $\mathbf{2 9 6 2 0 9 . 4 8}$ \\
\hline
\end{tabular}




\subsection{Analysis at the regional level}

We have analyzed the territorial schemes for the disposal and management of waste (Table 4). Five key blocks were identified for the analysis - separate garbage collection, morphological composition research, educational activities, incentives in the field of MSW management, and the use of the best technologies. A territorial waste management scheme is being formed. This task is assigned to the executive bodies of the constituent entities of the Russian Federation. Constituent entities are also in charge of waste accumulation procedures, tariffs, investment programs. Industrial waste is not mentioned in the bulk of territorial schemes. The Ministry of Industry and Trade is developing a digital service platform.

Table 4. Analysis of regional schemes for the disposal and management of waste by the presence of main activities in them.

\begin{tabular}{|l|c|c|c|c|c|}
\hline & $\begin{array}{c}\text { Separate } \\
\text { collection } \\
\text { of MSW }\end{array}$ & $\begin{array}{c}\text { Studies for } \\
\text { morphological } \\
\text { composition }\end{array}$ & $\begin{array}{c}\text { Educational } \\
\text { activities }\end{array}$ & $\begin{array}{c}\text { Stimulating } \\
\text { the sphere } \\
\text { of MSW } \\
\text { handling }\end{array}$ & $\begin{array}{c}\text { Application } \\
\text { of the best } \\
\text { technologies }\end{array}$ \\
\hline $\begin{array}{l}\text { Republic of } \\
\text { Tatarstan }\end{array}$ & + & + & + & + & + \\
\hline Moscow Region & + & + & + & + & + \\
\hline Moscow & + & + & + & + & + \\
\hline PrimorskyTerritory & + & + & + & - & - \\
\hline $\begin{array}{l}\text { Kaliningrad } \\
\text { Region }\end{array}$ & + & - & + & + & + \\
\hline
\end{tabular}

According to studies of the quantity and morphological composition of solid household waste in the Moscow region, conducted in the territorial scheme, it can be seen that the sorted waste is about $37 \%$ (paper-19\%, glass- $12 \%$, metal- $6 \%$ ). (Figure 1)

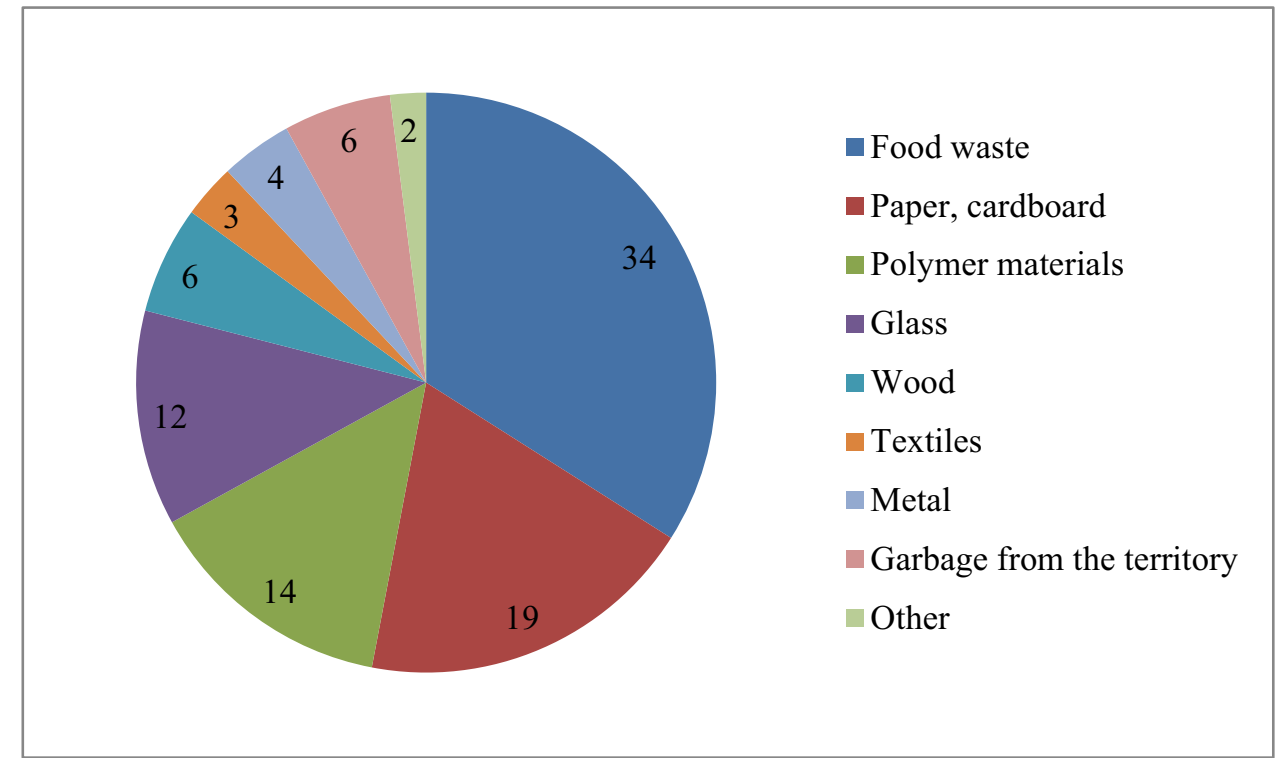

Fig. 1. Morphological composition of solid household waste in the Moscow region [17].

Since January 2020, the Primorsky Ecological Operator RSUE began operating in the Primorsky Territory. There was almost no infrastructure for separate collection of MSW. Thus, it was required to purchase containers for MSW in rural areas. And at the end of 
2020, the regional operator installed 8 thousand new containers. The regional budget allocated 200 million rubles in subsidies for the purchase and arrangement of containers. Garbage collection is handled by 40 shipping companies, which have about 250 garbage trucks. The inhabitants of the region have repeatedly raised questions about the implementation of the waste reform. Three waste sorting complexes have been built in the region in Khorolsky, Dalnerechensky and Pozharsky districts of the region.

In 2019, 43 garbage trucks were purchased. A total of 167 units of equipment are functioning. In 2020, the city has 60 sites for separate waste collection. In the Kaliningrad region, it is planned to build a complex for the processing and disposal of MSW. This will allow the closure of two landfills operating in the region. There is no infrastructure for separate waste collection in the city yet.

There are two regional operators in the Republic of Tatarstan - LLC "Grinta" and LLC "UK PGKH". An analysis of official documents showed that the republic generated 1.6 million tons of solid municipal waste in 2019. It is planned to increase recycling to $50 \%$ by 2035. Representatives of regional operators argue that the implementation of separate waste collection is not yet possible due to the lack of the necessary infrastructure. They honestly admit that revenue from the sale of recyclables is low-margin. In Kazan, the population is dissatisfied with the construction of an incineration plant.

The city of federal significance Moscow does not apply the provisions of federal legislation on the creation of a regional operator until January 1, 2022. The capital creates $1 / 5$ of all domestic waste in Russia (8 million tons). Accordingly, it is the city with the largest waste turnover, which requires systemic interventions. The following transport companies operate in Moscow -"Ecoline", "Spetstrans", "Hartiya", "MSK-NT".

Since January 2020, new sites for separate collection of solid household waste have been equipped. Containers of two colors are installed on the platforms. In 2020, about 23 thousand such platforms were equipped, and more than 60 thousand containers were installed on them. In addition, new garbage trucks have been purchased and there are now more than a thousand of them. And all the changes were carried out on the basis of the requirements of the Moscow Department of Housing. In addition, all garbage trucks are equipped with a special movement control system - a Global navigation satellite system. The control is carried out by the automated control system "United Dispatching Service of the Department of Housing of the City of Moscow".

In the Moscow Region, the waste reform began in 2019. The region is divided into 7 clusters in the territorial disposal scheme. Five landfills will be withdrawn and modernized. In order to reduce the cost of transporting solid municipal waste, the use of two-stage waste transportation has been expanded. Waste transfer stations, where incoming waste is pressed into transport batches, and waste sorting complexes act as an intermediate link in transportation. Within the framework of the national project "Ecology", 12 waste processing enterprises with a total capacity of 8.2 million tons per year will operate in the Moscow Region [18, 19].

Thus, eight new waste management company (WMC) were commissioned in Zaraysk, Serebryanye Prudy, Roshal, Kolomna, Yegoryevsk, Klin, Sergiev-Posad, and Kashira (Fig. 2). All this will allow the closure or modernization of the remaining 11 old landfills. Electronic control over the activities of regional operators is implemented in the AIS "Waste". The pilot project of RT Invest is the construction of waste-to-energy plants in the Moscow Region and Tatarstan. In the Moscow Region, it is planned to build 4 plants with a capacity of up to 700 thousand tons and $70 \mathrm{MW}$ each. There is 1 plant in Kazan with a capacity of 550 thousand tons.

According to the statistics of the Moscow region operators, the collected payments are distributed as follows: the costs of collection and transportation, processing, neutralization, disposal, costs of maintenance and contract support. The profit of operators in the Moscow 
Region is only $0.6-1 \%$. In the course of the reform, experts note low collection rates and poor financial condition of waste operators.

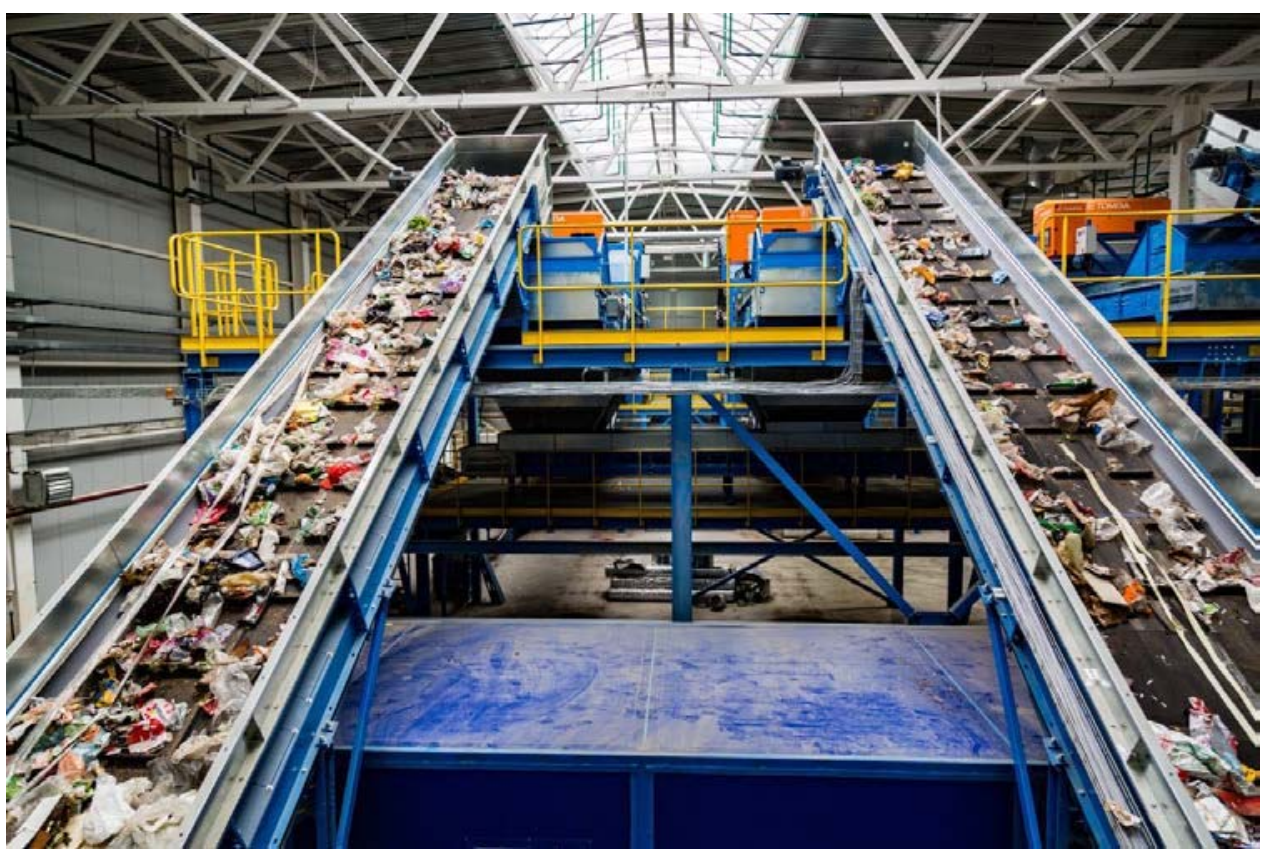

Fig. 2. The waste management company "East".

Qualitative content analysis showed that: not all regions have provided measures for the introduction of separate waste collection in their regional programs; it is compensation of part of the capital costs of regional operators for the implementation of investment projects; the evolution of legislative policy is based on the principle of movement towards the cheapest and most affordable economic solutions; it is necessary to increase the amount of the environmental fee; risks of bankruptcy of some regional operators due to the unstable financial situation.

\section{Discussion}

The strategic objectives set by the national project must be confirmed by budget expenditures. But, alas, there is not even full funding for the industry competence center "Russian environmental operator" created with such difficulty. The industry is not interesting for investors, and the national project does not have a mechanism for attracting extra-budgetary funds. And one of the conclusions of the Accounts Chamber can be supported: the existing support measures are insufficient for the effective implementation of investment projects in order to achieve the indicators of the federal project "Integrated MSW Management System”. Regional programs for waste management require revision, including in terms of measures to prevent the formation of MSW and return them to economic (commercial) turnover, as well as the implementation of a set of measures to exclude the construction of new landfills. And the last aspect: the Russian environmental operator should not turn into an observer, but share the responsibility. The risks that are present during any reform cannot only be borne by regional operators. In this case, conditions are created for the bankruptcy of private operators and, as a result, the threat of 
termination of the provision of one of the most important public services in a number of regions.

\section{Conclusion}

The review and analysis of problems in the field of solid waste disposal in Russia, the stages of implementation of the "garbage reform" are considered. To reform the waste management system, it is important to hold public hearings [20]. The problems of the transition of Russian operators to waste recycling are considered, and examples of implementation since the beginning of the reform are presented. On the example of the implementation of the reform, tested in the Moscow and Kaliningrad regions and the Primorsky Territory, the Republic of Tatarstan some approaches to solving problems in the field of environmental protection are shown. The analysis of territorial schemes and other regulatory documents on the implementation of the garbage reform is carried out.

\section{References}

1. E. Amasuomo, J. Baird, Journal of Management and Sustainability 6(4), 88-96 (2016)

2. A. Oke, J. Kruijsen, Recycling 1, 271-285 (2016) https://doi.org/10.3390/recycling1020271

3. The sustainable development goals Report (World Bank Report, New York, 2019) https://unstats.un.org/sdgs/report/2019/The-Sustainable-Development-Goals-Report2019.pdf

4. Communication from the European Parliament the Council, the European Economic and Social Committee and the Committee of the Regions, Closing the Loop-An EU Action Plan for the Circular Economy (European Commission, Brussels, Belgium, 2015)

5. J.A. Mathews, H. Tan, Journal of Industrial Ecology 15, 435-457 (2011) https://doi.org/10.1111/j.1530-9290.2011.00332.x

6. B. Su, A. Heshmati, Y. Geng, X. Yu, Journal of cleaner production 42, 215-227 (2013) https://doi.org/10.1016/j.jclepro.2012.11.020

7. P. Ghisellini, C. Cialani, S. Ulgiati, Journal of Cleaning Production 114, 11-32 (2016) https://doi.org/10.1016/j.jclepro.2015.09.007

8. J.P. Kirchherr, M.Reike, M. Hekkert, Resources, conservation and recycling 127, 221232 (2017) https://doi.org/10.1016/j.resconrec.2017.09.005

9. L. Sorme, E. Voxberg, J. Rosenlund, S. Jensen, Recycling 2, 20 (2019) https://doi.org/10.3390/recycling4020020

10. N. Parvez, A. Agraval, A. Kumar, Recycling 4, 28 (2019) https://doi.org/10.3390/recycling4030028

11. Managing Municipal Solid Waste: A Review of Achievements in 32 European Countries (Publications Office of the European Union, Copenhagen, Denmark, 2013)

12. A. Allesch, P. Brunner, Waste Management \& Research 30(6), 461-473 (2014)

13. E. Gentil, A. Damgaard, M. Hauschild et al., Waste Management 30(12), 2636-2648 (2010)

14. What a Waste 2.0. A Global Snapshot of Solid Waste Management to 2050 (2018) https://openknowledge.worldbank.org/bitstream/handle/10986/30317/211329ov.pdf?se quence $=11$ 
15. Environmental situation in Russia: monitoring (2019) https://wciom.ru/analyticalreviews/analiticheskii-obzor/ekologicheskaya-situacziya-v-rossii-monitoring

16. Accounts Chamber of the Russian Federation "Analysis of the implementation of measures to ensure the environmental safety of the Russian Federation in terms of eliminating accumulated harm objects and forming an integrated system for MSW management"

https://ach.gov.ru/upload/iblock/41b/41b02dc50697e6fc57ec2f389a8b68f0.pdf

17. Territorial scheme of waste management in the Moscow region (2020) https://mgkh.mosreg.ru/dokumenty/normotvorchestvo/obshestvennye-obsuzhdeniyaproektov-normativno-pravovykh-aktov/13-04-2020-12-50-58-proekt-territorialnoyskhemy-obrashcheniya-s-otkho

18. Resolution of the government of Moscow No. 734-PP of June 18, 2019 "On the implementation of measures for the separate collection (accumulation) of solid municipal waste in the city of Moscow" (2019)

19. N. Abramova, E3S Web of Conferences 217, 04012 (2020) https://doi.org/10.1051/e3sconf/202021704012

20. N. Danilina, Z. Ivanova, E3S Web of Conferences 135, 04014 (2019) https://doi.org/10.1051/e3sconf/201913504014 